
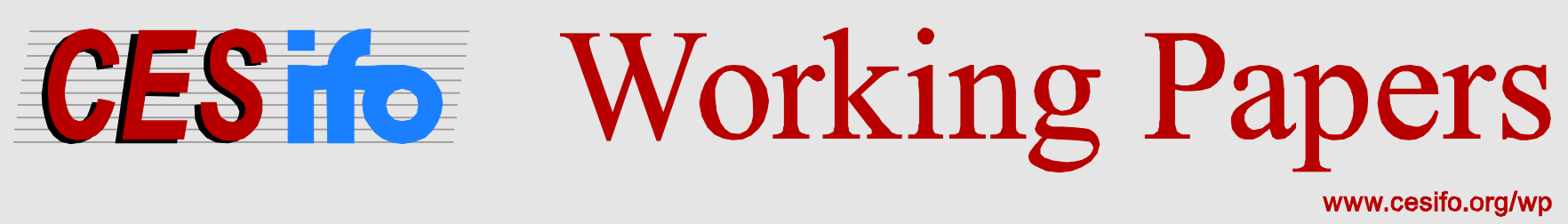

\title{
Exposure to Female Colleagues Breaks the Glass Ceiling - Evidence from a Combined Vignette and Field Experiment
}

\author{
Henning Finseraas \\ Åshild A. Johnsen \\ Andreas Kotsadam \\ Gaute Torsvik
}

CESIFO WORKING PAPER NO. 5565

CATEGORY 4: LABOUR MARKETS

OCTOBER 2015

An electronic version of the paper may be downloaded

- from the SSRN website:

- from the RePEc website:

- from the CESifo website:

WWw.SSRN.com

www.RePEc.org

www.CESifo-group.org/wp 


\title{
Exposure to Female Colleagues Breaks the Glass Ceiling - Evidence from a Combined Vignette and Field Experiment
}

\begin{abstract}
Increased diversity in the workforce can lead to either more or less discrimination. We study discrimination among recruits in the Norwegian Armed Forces during boot camp. In a vignette experiment female candidates are perceived as less suited to be squad leaders than their identical male counterparts. Adding positive information leads to higher evaluations of the candidates, but does not reduce the amount of discrimination. The boot camp provides an ideal setting for studying inter-group contact. We find that intense collaborative exposure to female colleagues reduces discriminatory attitudes: Male soldiers who were randomly assigned to share room and work in a squad with female soldiers during the recruit period do not discriminate in the vignette experiment.
\end{abstract}

Keywords: discrimination exposure field experiments.

\author{
Henning Finseraas \\ Institute for Social Research \\ Oslo / Norway \\ henning.finseraas@samfunnsforskning.no \\ Andreas Kotsadam \\ University of Oslo \\ Oslo / Norway \\ andreas.kotsadam@econ.uio.no
}

\author{
Åshild A. Johnsen \\ Institute for Social Research \\ Oslo / Norway \\ aaajohnsen@gmail.com \\ Gaute Torsvik \\ University of Oslo \\ Oslo / Norway \\ gaute.torsvik@econ.uio.no
}

\section{$8^{\text {th }}$ October 2015}

Thanks to The Norwegian Defense Research Establishment (FFI), in particular to Frank Steder and Torbjørn Hanson. This study could not have been conducted without the help of FFI and their project "Research on Cohorts". The paper has benefited from comments from Sara Cools, Raquel Fernandez, Magnus Johannesson, Arnfinn H. Midtbøen, and Øyvind Skorge as well as seminar participants at the University of Bergen, University of Oslo, University of Stavanger, Norwegian Social Research, Linnaeus University, and NOVA. We thank Ada Fuglset, Eirik Strømland, and Wiktoria Szczesna for excellent research assistance. Thanks also to the soldiers and staff at the North Brigade. The project is part of the research activities at the Centre for the Study of Equality, Social Organization, and Performance (ESOP) at the Department of Economics, University of Oslo. ESOP is supported by the Research Council of Norway. 


\section{Introduction}

There are significant gender differences in labor market outcomes across the world. In particular, there is a large under-representation of women at higher levels of the corporate ladder. In Europe, women account for less that 12 percent of board directors, despite accounting for 45 percent of the labor force (Pande and Ford, 2011), and less than 15 percent of executive officers in US Fortune 500 companies are women (Bertrand et al., 2014). This vertical segregation is commonly referred to as the glass ceiling. Despite being considered a country with a high degree of gender equality, the glass ceiling is clearly evident also in Norway (Schwab et al., 2014). ${ }^{1}$

A common argument in favor of female quotas is that exposure to female colleagues and leaders is necessary to change biased perceptions. To increase our understanding of the role biased perceptions and discrimination play for the glass ceiling, we ran a vignette experiment on recruits in the Norwegian Armed Forces. At the end of 8 weeks of booth camp, the male soldiers are asked to evaluate a candidate for a squad leader position. The soldiers were either asked to evaluate a male or a female candidate, which was decided by random draw. Except for the gender specific name, the male and the female candidate had identical qualifications. As soldiers are randomly allocated to rooms during this period, a random sample of the male soldiers were "treated" with female soldiers as room mates and colleagues (a room defines a squad in the boot camp). Hence, we are able to study how random exposure to female soldiers affect the male soldiers.

We find that the female candidate is ranked lower than the male candidate. Adding positive information (physical strength and leadership experience) to the candidates' resumes improve the evaluations of the candidates, but it does not reduce gender discrimination. However, living and working together with a female recruit in a squad has a strong causal impact on the male soldiers perception of female leadership. Those who are treated with female soldiers in their squad do not discriminate when they evaluate the squad leader candidate.

There is an extensive literature applying vignette studies, correspondence studies, and audit tests to study discrimination (Azmat and Petrongolo (2014),

\footnotetext{
${ }^{1}$ In Norway the gender gap in wages is 50 percent higher among college graduates than among full time working men and women in general, and before quotas were introduced in corporate boards only 5 percent of board members were women (Bertrand et al., 2014).
} 
Guryan and Charles (2013), Midtbøen (2014), Pager (2007), Riach and Rich (2002), and Rich (2014) provide extensive surveys of the literature). We move beyond merely identifying discrimination, and the main contribution of the paper is that we examine how exposure affects discrimination. An understanding of how to decrease discrimination and changing norms is argued to be lacking in the literature (Azmat and Petrongolo, 2014). We contribute to the literature on peer effects by testing how exposure to female colleagues affects attitudes towards women that wants to take a leader position. We examine exposure in a context that is close to ideal with respect to the conditions for bias reduction specified in inter-group contact theory, namely one of equal status, common goals, cooperation, and enforcing authority (Allport, 1954; Pettigrew, 1998). We identify the peer effects by separating men and women in the estimation, and hence follow recent advances in the peer-effects literature (Angrist, 2014).

Random exposure to female village leaders in India (Beaman et al., 2009), and to black roommates in college (e.g. Boisjoly et al. 2006) or in the US Air Force (Carrell et al. 2015), and to second generation immigrants in the Norwegian Armed Forces (Finseraas and Kotsadam 2015), has been shown to reduce bias. To the best of our knowledge, however, the question of whether peer exposure to female colleagues reduces the amount of discrimination has not been tested before. Finally, previous literature has identified a clear pattern, whereby gender discrimination covaries positively with the gender composition of the sector of employment (Albert et al. 2011; Booth and Leigh 2010; Carlsson 2011; Correll et al. 2007; Firth 1982; Guryan and Charles 2013; Levinson 1975; Neumark et al. 1996; Petit 2007; Riach and Rich 1987, 2006; Rich 2014; Weichselbaumer 2000; Zhou et al. 2013). The Norwegian Armed Forces have fewer women in top positions than any other Norwegian sector, including the church (Teigen, 2014). Hence our results are of interest in order to understand the advancement of women in a hyper male setting.

\section{Exposure and discrimination}

The discrimination literature often acknowledges that exposure to the discriminated group is potentially important, but valid empirical tests are difficult to implement because of non-random variation in exposure. Experimental analyses are sometimes combined with observational data on attitudes or the ethnic mix of the area to shed light on how exposure affects discrimination (e.g. Doleac and Stein 2013; Ewens et al. 2014). However, self-selection into areas implies 
that these studies do not necessarily capture the effect of exposure. We avoid such selection problems since we randomly assign males to share room with female soldiers during the first eight weeks of their military service. The room is an important unit during this period. Apart from living together, roommates solve a number of tasks together, and operate as a team within the platoon.

Theoretically, exposure to the discriminated group may decrease or increase bias, and its effect is likely to depend on the type of exposure, and the setting in which contact takes place. If exposure takes place in a competitive environment, bias is more likely to increase (e.g. Semyonov et al. 2006). The so called intergroup contact theory (Allport, 1954; Pettigrew, 1998) argues that prejudice and negative stereotyping of minorities might decline with contact with out-group members, but only under some conditions: Contact will reduce discrimination only if those in contact have equal status in the particular context, if they share common goals, if they are in a cooperative context, and if the contact takes place under some form of authority (see Pettigrew (1998)). Hence, given the setting in which our soldiers are interacting, we therefore expect contact to decrease bias: Soldiers of private rank have equal social status within the army, they share the common goals of the unit, they need to cooperate to solve their tasks, and contact takes place in a context with an explicit, enforcing authority. In fact, the army explicitly promote views of unity and equality among soldiers of the same rank.

There are different reasons why exposure could reduce discrimination in the setting we study in this paper. The most straightforward mechanism is that exposure leads to experiences that makes men update their beliefs about the suitability of female leaders (as suggested by Carrell et al. (2015) to be the reason for why interracial exposure reduces bias). Other reasons may be linked to identity, homosociality, and critical mass. Norms about gender differences are salient in leadership perceptions in male dominated settings (Ridgeway and Correll, 2004), and as people tend to favor leaders that are similar to themselves, a self-fulfilling process of homosocial reproduction may occur (Kanter, 1977a,b). A qualitative field study of gender mixed rooms (including the camps of the soldiers in our sample) was conducted after the boot-camp period. This study concludes that mixed rooms reduces gender essentialist notions, and increases feelings of sameness among the soldiers (Hellum, 2015). Hence, it is possible that intense exposure makes male soldiers perceive themselves as more similar to female soldiers and therefore less skeptical to having them as leaders.

A handful of studies have found that exposure to peers with other char- 
acteristics reduces biased perceptions. Boisjoly et al. (2006) find that white students who were randomly assigned to live with an African-American in college were more positive towards African-Americans and towards affirmative action, than were white students who had white roommates. Carrell et al. (2015) find that white freshman cadets at the U.S. Air Force Academy become more positive towards blacks if randomly assigned to squadrons with black students, and Van Laar et al. (2005) find improved inter-group attitudes among college students using randomized exposure.

\section{The Experiments}

\subsection{The Field Experiment}

Military service is mandatory for men in Norway. Despite practicing conscription, Norway does not draft all eligible citizens and about one in six men are conscripted. Since 2010, screening and testing for military service has been mandatory for both genders, but women serve on a voluntary basis. Our sample includes all incoming soldiers in the August 2014 contingent to the The Second Battalion of the North Brigade of the Norwegian Armed Forces.

The soldiers met on their first day of service at a military camp close to Oslo. They are tested for medical and psychological fitness, and flown to Northern Norway if they pass the tests. The soldiers attend a session with a questionnaire during this day, which includes questions on motivation, intentions to attend higher education, as well as a set of background characteristics. The soldiers are not told the purpose of the study. The instructor stressed that the survey results are for research purposes only, and that it is anonymous to all representatives of the armed forces. At the point of testing, the soldiers have never met before, and they do not know with whom they are going to share rooms with until they arrive in Northern Norway. Hence, the first survey constitutes the baseline data for the field experiment.

In Northern Norway soldiers are immediately assigned to the rooms where they will stay during the whole recruit period (the boot camp). The key feature of our experiment is that we randomized the composition of the rooms. Concretely, the Armed Forces provided us with a list of soldiers (anonymous reference numbers) and information about gender, in addition to information about available rooms. Based on this information we randomly allocated the soldiers into different rooms and returned the list to the Armed Forces. The 
allocation was completely random within the platoons, except for a decision rule which assigns at least two women to the same room if possible. The "two-ifpossible" decision rule was a requirement from the Armed Forces. ${ }^{2}$

The boot camp is period of intense training, and soldiers spend much time with their roommates. They perform various tasks together, such as cleaning the room for inspection each morning. They also serve in the same platoon, and they constitute a squad within the platoon. There are strict rules for what soldiers can and cannot do during the boot camp - they have to wear uniforms at all times, and are not allowed to sleep outside of the base.

After eight weeks we survey the soldiers a second time, and link their answers to the first round using an anonymous reference number for each soldier. At this time we conduct the vignette experiment to see whether 8 weeks of exposure can affect the soldiers' perceptions about female leaders.

\subsection{The Vignette Experiment}

To detect discrimination, we present to the soldiers a hypothetical (but realistic) case description of a candidate applying for a position as squad leader. We chose a position in the military, as it is a position which all of the soldiers can relate to.

The soldiers are asked to rate the fictional candidate on a scale from 1 to 6 based on a short text, presented in Table 1. The experiment consists of four between-subject treatments. The treatments differ with respect to the gender of the candidate, and in how much information they receive about the candidate. In the first treatment ("Ida basic"), the soldiers are provided with basic information about the female Ida Johansen: They get information about her high school grades, career plans, family background, and motivation. The second treatment ("Ida more") provides more information about the candidate: In addition to the basic information, they get information about her physical capacity and her leadership experience (in bold text). We provide information on physical strength and leadership experience because these characteristics of the candidates are relevant for the position. Although one might argue that this framing could prime the subjects to discriminate, our aim is not to study discrimination per se, but to examine whether exposure to female soldiers affect

${ }^{2}$ There are rooms with only one woman despite this rule. There are several reasons for this: i) that there was only one woman in the platoon, ii) that the number of women was uneven and they did not want too many women in one room, or iii) that some women left the army during the first weeks (albeit not to a stronger degree than the male soldiers, since we find that attrition is unrelated to treatment status and gender). 
this type of discrimination.

The other two treatments are identical to "Ida basic" and "Ida more", with the exception that the female name Ida Johansen is replaced by the male name Martin Hansen. The forenames are gender specific, and to avoid any name effects, we chose, as in Carlsson and Eriksson (2014), the most common names of the soldiers' age group. The surnames are the most common in Norway (Statistics Norway, 2014).

Table 1: From the instructions.

\section{SQUAD LEADER}

The unit is choosing new squad leaders. The squad leader is the link between officers and soldiers. For some, this position can be very physically and mentally demanding. The position requires high skills. As squad leader, one is responsible not just for oneself, but also for the team.

\section{A potential candidate}

Name: Ida Johansen/ Martin Hansen

- Grades from high school: 4.1 (average).

- Career plans: Does not wish to continue in the armed forces, plans to pursue higher education in the field of economics and administration.

- Family background: Has a sister, dad is an engineer, and mother is a teacher. Comes from a middle-sized city in the eastern part of Norway.

- Motivation: Thinks that serving in the armed forces is both meaningful and important.

- Physical capacity: Among the top 20 percent in his/ her cohort (armed forces). Exercise regularly.

- Leadership experience: Was the leader of a youth organization.

Ida Johansen/ Martin Hansen would very much like to become a squad leader, indicate how well suited you think he/ she is for the job: (1=very badly, $6=$ very well) - put a circle around your choice.

$\begin{array}{llllll}1 & 2 & 3 & 4 & 5 & 6\end{array}$

We ran the experiment on September 26, 2014, and in total 413 people participated in eight sessions. Session sizes vary depending on the size of the room where we conducted the experiment, and on when the soldiers were available for participation, see Table 2. The experiment was conducted on a military base, and soldiers used pen and paper in the vignette experiment. 
Table 2: Session Statistics

\begin{tabular}{ccccc}
\hline Session & Room & Subjects & Males & Males living with females \\
\hline 1 & Small & 31 & 29 & 6 \\
2 & Big & 29 & 27 & 5 \\
3 & Big & 65 & 63 & 11 \\
4 & Big & 70 & 67 & 21 \\
5 & Small & 23 & 22 & 4 \\
6 & Big & 107 & 92 & 15 \\
7 & Small & 33 & 29 & 7 \\
8 & Small & 40 & 38 & 9 \\
\hline Total & 8 sessions & 398 & 367 & 78 \\
\hline
\end{tabular}

Note: Observations with missing or erroneous information about rooms or candidate number were dropped (15 observations).

In all the following tables, we restrict the sample to men only, for reasons that are explained in Section $4 .^{3}$ In Table 3, we see the raw difference across cases in how they are evaluated as squad leaders. The male candidate is given a higher score than the female candidate. More information leads to more positive evaluations, but it does not reduce discrimination.

There are no statistically significant differences in the background characteristics of the soldiers across the four treatments. As we also present results with the treatments pooled by gender, we present the differences across the pooled cases in Table 4, and we see that they are only statistically significantly different with respect to one background variable (mothers education) and only at the 10 percent level. We will present regression results both with and without controlling for the background characteristics of the soldiers.

\footnotetext{
${ }^{3}$ The results from the basic vignette experiment, as well as summary statistics, for the whole sample are presented and discussed in the Appendix.
} 
Table 3: Descriptive statistics across assigned cases

\begin{tabular}{|c|c|c|c|c|c|c|c|c|}
\hline & \multicolumn{2}{|c|}{$\begin{array}{c}(1) \\
\text { Ida basic }\end{array}$} & \multicolumn{2}{|c|}{$\begin{array}{c}(2) \\
\text { Martin basic }\end{array}$} & \multicolumn{2}{|c|}{$\begin{array}{c}(3) \\
\text { Ida more }\end{array}$} & \multicolumn{2}{|c|}{$\begin{array}{c}(4) \\
\text { Martin more }\end{array}$} \\
\hline & Mean & SD & Mean & SD & Mean & SD & Mean & SD \\
\hline Dependent variable & & & & & & & & \\
\hline $\begin{array}{c}\text { Score on the candidate } \\
(1=\text { very bad, } 6=\text { very good })\end{array}$ & 3.771 & $(1.004)$ & 4.145 & $(0.926)$ & 4.376 & $(0.893)$ & 4.720 & $(0.817)$ \\
\hline Background characteristics & & & & & & & & \\
\hline Mother has high education & 0.763 & $(0.428)$ & 0.620 & $(0.488)$ & 0.707 & $(0.458)$ & 0.685 & $(0.467)$ \\
\hline Father has high education & 0.882 & $(0.325)$ & 0.797 & $(0.404)$ & 0.837 & $(0.371)$ & 0.815 & $(0.390)$ \\
\hline Mother works & 0.855 & $(0.354)$ & 0.886 & $(0.320)$ & 0.868 & $(0.340)$ & 0.902 & $(0.299)$ \\
\hline Father works & 0.947 & $(0.225)$ & 0.962 & $(0.192)$ & 0.989 & $(0.105)$ & 0.978 & $(0.147)$ \\
\hline Parents are divorce & 0.276 & $(0.450)$ & 0.253 & $(0.438)$ & 0.366 & $(0.484)$ & 0.253 & $(0.437)$ \\
\hline Plan higher education & 0.750 & $(0.436)$ & 0.633 & $(0.485)$ & 0.774 & $(0.420)$ & 0.750 & $(0.435)$ \\
\hline IQ & 5.795 & $(1.488)$ & 5.602 & $(1.306)$ & 5.810 & $(1.555)$ & 5.687 & $(1.353)$ \\
\hline$N$ (on dependent variable) & 83 & & 83 & & 101 & & 100 & \\
\hline
\end{tabular}

Table 4: Descriptive statistics across the pooled cases

\begin{tabular}{lllll}
\hline & \multicolumn{2}{c}{$(1)$} & \multicolumn{2}{c}{$(2)$} \\
& Mda & \multicolumn{2}{c}{ Martin } \\
& Mean & SD & Mean & SD \\
\hline Dependent variable & & & & \\
$\quad$ Score on the candidate & 4.103 & $(0.989)$ & 4.459 & $(0.912)$ \\
(1=very bad, 6=very good) & & & & \\
Background characteristics & & & & \\
Mother has high education & $0.732^{*}$ & $(0.444)$ & 0.655 & $(0.477)$ \\
Father has high education & 0.857 & $(0.351)$ & 0.807 & $(0.396)$ \\
Mother works & 0.862 & $(0.346)$ & 0.895 & $(0.308)$ \\
Father works & 0.970 & $(0.171)$ & 0.971 & $(0.169)$ \\
Parents are divorced & 0.325 & $(0.470)$ & 0.253 & $(0.436)$ \\
Plan higher education & 0.763 & $(0.426)$ & 0.696 & $(0.461)$ \\
IQ & 5.803 & $(1.521)$ & 5.648 & $(1.329)$ \\
\hline$N$ (on dependent variable) & 184 & & 183 & \\
\hline
\end{tabular}




\section{Empirical strategy}

\subsection{Detecting discrimination and separating between types of discrimination}

To test if female candidates are given a lower score than male candidates we estimate the following equation:

$$
\text { Score }_{i r t 2}=\alpha_{J}+\gamma_{S}+\beta_{1} \text { Female candidate }_{i r}+\beta_{n} X_{i r t 1}+\epsilon_{i r}
$$

Where the variable Score for individual $i$ in room $r$ at time $t 2$ is the score given to the candidate in the vignette. $\alpha_{J}$ refers to platoon fixed effects, $\gamma_{S}$ are session fixed effects, Female candidate is a dummy variable that equals 1 if the candidate is female (Ida), and 0 if the candidate is male (Martin). Hence, $\beta_{1}$ is our measure of discrimination against women. $\mathrm{X}$ is a vector of control variables collected at baseline (including parents' education, marital status, and employment status, the individuals' plans for taking higher education, and IQ score). We present results with and without these controls.

The fact that our outcome variable is the score from one to six implies that we circumvent a well-known problem in correspondence studies, namely that potential differences in variance across groups in combination with a cutoff value for hiring renders discrimination unidentified (Heckman and Siegelman, 1993; Heckman, 1998; Neumark, 2012). Guryan and Charles (2013) offer the example of a hiring situation where candidates are matched at a level of skills that is low relative to the hiring threshold. In such a case, the more heterogeneous group (with respect to skills) will have a higher share exceeding the threshold for hiring. In the opposite case, where candidates are matched at a relatively high level, the less heterogeneous group will have a higher share exceeding the hiring threshold (see Carlsson et al. (2014) for a very illustrative graphical exposition of the problem). ${ }^{4}$ In our case, the evaluation of the candidate is linear on a scale from one to six, and hence we can recover the average evaluation without having to depend on a cutoff value.

\footnotetext{
${ }^{4}$ Neumark (2012) develops a method to work around this problem by testing how the discrimination changes when adding more positive information to the candidates. Crucially, this added information must be assumed to be equally correlated with the perceived productivity of the candidates across the groups. Such an assumption is often difficult to defend empirically and it further precludes a separation of the discrimination into taste-based and statistical discrimination.
} 
Recent studies on discrimination has attempted to separate between tastebased and statistical based discrimination, and adding more information has become a standard way to try to identify statistical discrimination (e.g. Ahmed et al. 2010; Andersson et al. (2012); Ewens et al. 2014; List 2004; Zussman, 2013; and Doleac and Stein 2013). ${ }^{5}$ If there is less discrimination when more positive attributes are added, we can conclude that the observed discrimination is statistical with respect to those attributes. We follow this approach and add positive information and use a difference in difference approach in order to identify statistical discrimination. This is done by estimating equation 2 :

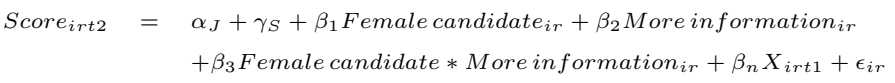

Where More information $_{\text {ir }}$ is a dummy variable equal to 1 if the respondent receives the treatment with added information. The interaction term, Female candidate $_{\text {ir }} *$ More in formation $_{\text {ir }}$, captures the difference in the effect of added information for the female and the male candidate.

\subsection{Exposure}

Peer effects interest social scientists across a range of disciplines (see Sacerdote, 2011, for a review of the literature). The notion that our beliefs and attitudes are affected by the people we interact with, is a commonly held belief. Yet it turns out to be difficult to test, because people generally self select into networks and the whole group usually face a similar environment (Manski, 1993). We solve this issue by randomly allocating soldiers into rooms. Angrist (2014) argues that the most compelling evidence on peer effects comes from studies where there is a clear separation of the individuals thought to be affected, and the peers thought to affect them. ${ }^{6}$ For this reason, we limit the

\footnotetext{
${ }^{5}$ In models of taste-based discrimination, differential treatment is a result of bias or prejudice towards members of a group (Becker, 1957). Statistical discrimination is a result of imperfect information, and is based on stereotyping (Phelps, 1972; Arrow, 1973).

6 This type of design is applied in Kling et al. (2007), who analyze the effects of neighborhoods on individuals who are randomly assigned to receive housing vouchers in the Moving to Opportunity program. The neighborhood effects are estimated by using characteristics of the neighbors, and no effects on the old neighbors are estimated. Similarly, Angrist and Lang (2004) investigate the effects of low-income peers in the classroom, where low-income individuals were bussed in as part of the Metco program. The low income students' own outcomes were not included in the regression, they were only used to calculate peer characteristics.
} 
sample to only men. The women will only be used to define the room characteristics. The following regression model will be estimated:

$$
\text { Score }_{\text {irt } 2}=\alpha_{J}+\gamma_{S}+\beta_{1} \text { Room Treatment }_{r}+\beta_{n} X_{\text {irt } 1}+\epsilon_{i r}
$$

Where Score $_{\text {irt } 2}$ refers to the Score given by individual $i$ in room $\mathrm{r}$ at time t2. RoomTreatment is a binary indicator equal to one if the respondent shared room with a female soldier, $\alpha_{J}$ refers to the platoon fixed effects, $\gamma_{S}$ are session fixed effects, while $\beta_{n}$ is the vector of coefficients of the covariates. In this specification, $\beta_{1}$ captures the causal effect of being assigned to a room with at least one woman. In order to investigate treatment intensity, we also run regressions with the share of women in the room. Since we compare soldiers within the same platoon, but with different treatment status at the room level, it is possible that there are spillovers effects. For instance, exposure to women in the platoon could also affect discriminatory attitudes. Hence, the effect we measure is the difference between intense exposure at the room and team level, in addition to any effect of exposure at the platoon level. We expect that the spillover reduces the estimated effect. Hence, our results are lower bound estimates of intense exposure to female colleagues.

\section{Results}

\subsection{Evidence for discrimination}

As we saw in Table 3, the female candidate with basic information receives the lowest score, while the male candidate with more information receives the highest score. We now test these differences formally. We start by asking if there is discrimination of female candidates, by regressing the score on the gender of the candidate, as described in equation 1 . In column 1 of Table 5 , we see that the female candidate is perceived as less suited to be a squad leader. Hence, there is discrimination of the female candidate by the male soldiers in our sample. The coefficient for female candidate in column 1 captures the combined effect across the cases with more and less information. In column 2, we add baseline controls, and the results are similar.

When adding positive information about the candidates, we test if discrimination is statistical based on the added information. Column 3 shows the 
difference in difference results where we separate the cases with and without information, as described in equation 2. We find that information improves the evaluation of both our male and female candidates, but it does not reduce the degree of discrimination. The interaction term is negative, implying that if anything, information helps the male candidate more, but the coefficient is not statistically significant. Adding baseline controls (column 4) yields similar results.

While the results are inconsistent with discrimination being statistical with respect to the information added, it is important to remember that our results do not allow us to conclude whether discrimination is taste-based or statistical. The results are consistent with the discrimination being taste-based, but they are equally consistent with discrimination being statistical with respect to relevant information about the squad-leader which is not included in the current vignette.

Table 5: Gender discrimination: Dependent variable is score of the candidate.

\begin{tabular}{lcccc}
\hline & $(1)$ & $(2)$ & $\begin{array}{c}(3) \\
\text { Less and more } \\
\text { Pooled }\end{array}$ & $\begin{array}{c}(4) \\
\text { information }\end{array}$ \\
\hline Female candidate & & & & \\
& $-0.326^{* * *}$ & $-0.365^{* * *}$ & $-0.275^{*}$ & $-0.318^{* *}$ \\
Information added & $(0.108)$ & $(0.103)$ & $(0.140)$ & $(0.143)$ \\
& & & $0.551^{* * *}$ & $0.456^{* * *}$ \\
Female candidate*Information & & & $(0.134)$ & $(0.135)$ \\
& & & -0.109 & -0.096 \\
Mean of dependent variable & 4.281 & 4.266 & 4.281 & 4.266 \\
Observations & 367 & 335 & 367 & 335 \\
R-squared & 0.128 & 0.191 & 0.190 & 0.232 \\
Platoon and Session FE & Yes & Yes & Yes & Yes \\
Baseline controls & No & Yes & No & Yes \\
\hline
\end{tabular}

Notes: The sample only includes male respondents. Standard errors clustered at the room level in parantheses. *** $\mathrm{p}<0.01, * * \mathrm{p}<0.05, * \mathrm{p}<0.1$

\subsection{Exposure reduces discrimination}

When we test whether random variation in exposure to female soldiers reduces discrimination, the analysis is restricted to men, and the female peers merely inform the treatment status. In total we have 89 rooms, with four to 
eight persons in each room. Eight percent of the soldiers are women and between zero and four women live in the rooms. The share of women in the rooms ranges from $0-0.67$ with a mean of 0.07 and a standard deviation of 0.15 . In total, 21 percent of the men are treated, i.e. they share room with at least one woman. The share of exposure for the treated varies from 17 to 67 percent and the full distribution of treatment shares is shown in Table 6. We see that the modal exposure rate is to have one-third of the soldiers in the room being female, conditional on having at least one women in the room.

Table 6: Share of women in the room for treated soldiers.

\begin{tabular}{lcc}
\hline Share of women in room & Number of exposed men & Percent \\
\hline $17 \%$ women in the room & 5 & 6.41 \\
$20 \%$ women in the room & 4 & 5.13 \\
$25 \%$ women in the room & 11 & 14.10 \\
$29 \%$ women in the room & 9 & 10.26 \\
$33 \%$ women in the room & 35 & 44.87 \\
$50 \%$ women in the room & 13 & 16.67 \\
$67 \%$ women in the room & 2 & 2.56 \\
\hline Total & 78 & 100 \\
\hline
\end{tabular}

In Table 7, we present coefficients and t-statistics from regressions of the treatment indicator dummy on the pre-determined variables. Platoon fixed effects are included in all regressions since room assignment is randomized within platoons.Session fixed effects are included since the vignette experiment took place within 8 different sessions. The table also reports an F-test of joint significance. The differences between the treatment and the control group are small, and not statistically significant. Most importantly, the small F-value in the joint test of whether all variables together predict treatment status allows us to conclude that the randomization was successful. 
Table 7: Regressions of treatment status on pre-determined variables.

\begin{tabular}{lcc} 
& Coefficient & t-statistic \\
\hline Mother has high education & 0.020 & 0.489 \\
Father has high education & 0.003 & 0.081 \\
Mother is employed & 0.023 & 0.517 \\
Father is employed & -0.039 & -0.476 \\
Parents are divorced & 0.017 & 0.319 \\
Plan to take higher education & 0.005 & 0.138 \\
IQ & 0.007 & 0.544 \\
\hline F-test of joint significance & $0.02(\mathrm{p}=.90)$ &
\end{tabular}

Note: Each row presents the results from one regression. Platoon and session fixed effects are included in all regressions. t-values adjusted for room clustering. $* * * \mathrm{p}<0.01, * * \mathrm{p}<0.05, * \mathrm{p}<0.1$

In column 1 of Table 8 , we present results based on regressing the score of the candidate on the gender of the candidate, a treatment dummy equal to 1 if sharing room with a female soldier, and treatment interacted with gender of the candidate. There is discrimination among men sharing room with only men (as shown by the negative and statistically significant coefficient for the female candidate not interacted with treatment). Men sharing room with women discriminate significantly less against women (as shown by the positive and statistically significant interaction term). These results show that the random intense, and relevant, exposure to women that comes from sharing room and being part of the same squad not only reduces discrimination, but actually eliminates it. The results are similar when we add baseline controls in column 2, albeit the interaction term is only statistically significant at the 10 percent level. In column 3, we interact treatment with adding information, and the results indicate that exposure reduces discrimination more strongly in combination with added information. Unfortunately, we do not have enough power to estimate the effects separately. Adding baseline controls yields similar results as seen in column $4 .^{7}$

\footnotetext{
${ }^{7}$ In columns 3-4 we find that the treatment group reacts less strongly to the information treatment. One explanation for this finding might be that men for some positions are valued higher than women due to an undervaluation of women's capacities and an overvaluation of men's capacities. It is possible that both these factors are affected by being treated. It is perhaps no longer seen as very important for the leadership position to be a very strong man once you have been exposed to other types of people that are equally fit to be leaders without such masculine characteristics.
} 
Table 8: Exposure and discrimination: Dependent variable is score of the candidate.

\begin{tabular}{|c|c|c|c|c|}
\hline & (1) & $(2)$ & $(3)$ & (4) \\
\hline & \multicolumn{2}{|c|}{ Treatment } & \multicolumn{2}{|c|}{ Information and Treatment } \\
\hline Female candidate & $\begin{array}{c}-0.430^{* * *} \\
(0.124)\end{array}$ & $\begin{array}{c}-0.438^{* * *} \\
(0.119)\end{array}$ & $\begin{array}{l}-0.277 \\
(0.170)\end{array}$ & $\begin{array}{c}-0.305^{*} \\
(0.179)\end{array}$ \\
\hline Information added & & & $\begin{array}{c}0.657 * * * \\
(0.153)\end{array}$ & $\begin{array}{c}0.550^{* * *} \\
(0.162)\end{array}$ \\
\hline Female*Information & & & $\begin{array}{l}-0.254 \\
(0.186)\end{array}$ & $\begin{array}{l}-0.232 \\
(0.203)\end{array}$ \\
\hline Treated & $\begin{array}{l}-0.230 \\
(0.145)\end{array}$ & $\begin{array}{l}-0.201 \\
(0.141)\end{array}$ & $\begin{array}{c}0.085 \\
(0.221)\end{array}$ & $\begin{array}{c}0.062 \\
(0.226)\end{array}$ \\
\hline Treated*Female candidate & $\begin{array}{c}0.513^{* *} \\
(0.204)\end{array}$ & $\begin{array}{l}0.358^{*} \\
(0.213)\end{array}$ & $\begin{array}{c}0.111 \\
(0.277)\end{array}$ & $\begin{array}{c}0.005 \\
(0.281)\end{array}$ \\
\hline Treated*Information & & & $\begin{array}{c}-0.493^{*} \\
(0.250)\end{array}$ & $\begin{array}{c}-0.437^{*} \\
(0.257)\end{array}$ \\
\hline Treated*Female candidate*Information & & & $\begin{array}{c}0.635 \\
(0.396)\end{array}$ & $\begin{array}{c}0.637 \\
(0.433)\end{array}$ \\
\hline Baseline controls & No & Yes & No & Yes \\
\hline Mean of dependent variable & 4.281 & 4.266 & 4.281 & 4.266 \\
\hline Observations & 367 & 335 & 367 & 335 \\
\hline R-squared & 0.139 & 0.196 & 0.204 & 0.242 \\
\hline Platoon and Session FE & Yes & Yes & Yes & Yes \\
\hline Baseline controls & No & Yes & No & Yes \\
\hline
\end{tabular}

In Table 9 we exploit the variation in treatment intensity and regress the share of women in the room on the evaluation of the candidate, as well as the interaction with evaluating a female candidate. In column 1 we see a large and highly statistically significant effect of the share of women in the room interacted with evaluating a female candidate. As the unit of measurement ranges from 0 to all females in a room, it implies an extrapolation, as there is by definition no man in a room with only women. In column 2 , we instead present standardized beta coefficients and the results show that a one standard deviation increase in the share of women (corresponding to an increase in the share of women of 15 percent) corresponds to a decline in the discrimination and an increase in the evaluation of the female candidate by 0.165 standard deviations. ${ }^{8}$

\footnotetext{
${ }^{8}$ It is possible that there is a non-linearity in the effect of share of women in the room. We have experimented with ways to model such a non-linearity, however, our ability to examine
} 
Table 9: Share of exposure and discrimination: Dependent variable is score of the candidate.

\begin{tabular}{lcc}
\hline & $(1)$ & $(2)$ \\
& Baseline & $\begin{array}{c}\text { Standardized } \\
\text { Beta coefficients }\end{array}$ \\
\hline Female candidate & $-0.434^{* * *}$ & $-0.225^{* * *}$ \\
Share of women & $(0.122)$ & $(0.001)$ \\
& -0.567 & -0.086 \\
Share of women*Female candidate & $(0.441)$ & $(0.202)$ \\
& $1.665^{* * *}$ & $0.165^{* * *}$ \\
\hline Observations & $(0.625)$ & $(0.009)$ \\
R-squared & 367 & 367 \\
Platoon and Session FE & 0.141 & 0.141 \\
\hline Standard & Yes & Yes \\
\hline
\end{tabular}

Standard errors are clustered on rooms in both regressions and are presented in parentheses in column 1 . The parantheses in column 2 presents p-values. $* * * \mathrm{p}<0.01, * * \mathrm{p}<0.05,{ }^{*} \mathrm{p}<0.1$

\section{Conclusion}

Fewer women than men reach higher levels of leadership, also in genderequal societies like Norway (Bertrand et al., 2014), and especially in the military (Teigen, 2014). Such differences can be explained by supply side factors, such as differences in preferences and differences in competitiveness across the sexes (Croson and Gneezy, 2009). The differences may, however, also stem from demand side discrimination, i.e., that men are valued more highly than women with identical qualities and aspirations. Discrimination may be statistical, in the sense that it is based on unbiased statistical inference, or it may be preference based, so that it is driven by negative attitudes or biased perceptions of women's abilities. This paper aims to shed light on three important questions related to gender discrimination. First, to what extent are women seeking leadership positions in a male dominant environments discriminated against? ${ }^{9}$ Second, if women are discriminated when two candidates are equally qualified for a job,

it is severely hampered by having few observations which implies a risk of overfitting.

${ }^{9}$ We do not directly examine whether women are seeking leadership positions since we have no such outcomes. Our results show how direct personal contact can reduce discrimination. Less discrimination can reduce the costs/ increase the expected outcome from seeking such positions for female candidates. In the event that female leader candidates pursue leadership positions to a lesser extent than men due to discrimination, reduced discrimination can hence affect female leader candidates' behavior. 
does it help to add more information? Third, does working together with women in a male dominant environment induce men to discriminate less against women aspiring for leadership roles?

Identifying the presence and the type of discrimination is difficult with observational data, as many of the factors that may influence the valuation of a candidate are not observed by the researcher. We use a vignette experiment to detect discrimination, and find that male soldiers give a fictitious male candidate for a squad leader position a higher score than an otherwise identical female candidate. A random sample of the soldiers got additional information on qualifications of the candidates. Providing additional positive information increased the rating of both candidates but did not, however, reduce the degree of discrimination.

What stands out in this study is that a random sample of male soldiers was allocated to share rooms with female soldiers. By sharing rooms, they also share the responsibility for many different tasks and they form a team within the platoon. We find that discrimination disappears if we expose male soldiers to female peers in an environment that is relevant for the leader position.

By combining a vignette experiment with a randomized field experiment, our results have strong internal validity. Previous literature finds discrimination of women in male dominated spheres (Azmat and Petrongolo, 2014), and we believe our results are generalizable to such settings. One should be careful in generalizing the results to settings where males dominate to a lesser extent, as dynamics are likely to be different. It is plausible that direct personal contact matters less in such settings than in male dominated settings. The particular selection of men and especially of women in our setting is similar to other male dominated settings. Limits to the external validity may arise, however, from other peculiarities of the military setting. The advantage of our context, in addition to the ability of establishing causality, is that we can derive the clear theoretical prediction that bias should be reduced. If our findings extend beyond the army setting, they have important policy implications. We have shown that the glass ceiling that prevents female candidates to obtain leader positions in a masculine context can be broken by exposure. 


\section{References}

Ahmed, A. M., L. Andersson And M. Hammarstedt, "Can discrimination in the housing market be reduced by increasing the information about the applicants?," Land Economics 86 (2010), 79-90.

Albert, R., L. Escot and J. A. Fernández-Cornejo, "A field experiment to study sex and age discrimination in the Madrid labour market," The International Journal of Human Resource Management 22 (2011), 351-375.

Allport, G. W., The Nature of Prejudice (Cambridge, MA: Addison-Wesley, 1954).

Andersson, L., N. Jakobsson and A. Kotsadam, "A field experiment of discrimination in the Norwegian housing market: Gender, class, and ethnicity," Land Economics 88 (2012), 233-240.

Angrist, J. D., "The perils of peer effects," Labour Economics 30 (2014), 98-108.

Angrist, J. D. AND K. LAng, "Does School Integration Generate Peer Effects? Evidence from Boston's Metco Program," American Economic Review (2004), 1613-1634.

Arrow, K., "The theory of discrimination," Discrimination in Labor Markets 3 (1973)

Azmat, G. and B. Petrongolo, "Gender and the labor market: What have we learned from field and lab experiments?," Labour Economics 30 (2014), $32-40$.

Beaman, L., R. Chattopadhyay, E. Duflo, R. Pande and P. Topalova, "Powerful Women: Does Exposure Reduce Bias?*," The Quarterly journal of economics 124 (2009), 1497-1540.

BeCKen, G. S., The economics of discrimination (University of Chicago press, 1957).

Bertrand, M., S. E. Black, S. Jensen and A. Lleras-Muney, "Breaking the glass ceiling? The effect of board quotas on female labor market outcomes in Norway," Technical Report, National Bureau of Economic Research, 2014. 
Boisjoly, J., G. J. Duncan, M. Kremer, D. M. Levy and J. Eccles, "Empathy or Antipathy? The Impact of Diversity," American Economic Review 96 (2006), 1890-1905.

Booth, A. And A. Leigh, "Do employers discriminate by gender? A field experiment in female-dominated occupations," Economics Letters 107 (2010), 236-238.

Carlsson, M., "Does hiring discrimination cause gender segregation in the Swedish labor market?," Feminist Economics 17 (2011), 71-102.

Carlsson, M. And S. ERIKsson, "Discrimination in the rental market for apartments," Journal of Housing Economics 23 (2014), 41-54.

Carlsson, M., L. Fumarco and D.-O. Rooth, "Does the design of correspondence studies influence the measurement of discrimination?," IZA Journal of Migration 3 (2014), 1-17.

Carrell, S. E., M. Hoekstra and J. E. West, "The Impact of Intergroup Contact on Racial Attitudes and Revealed Preferences," Technical Report, National Bureau of Economic Research, 2015.

Correll, S. J., S. Benard and I. Paik, "Getting a Job: Is There a Motherhood Penalty? 1," American journal of sociology 112 (2007), 1297-1339.

Croson, R. And U. Gneezy, "Gender differences in preferences," Journal of Economic literature (2009), 448-474.

Doleac, J. L. AND L. C. Stein, "The visible hand: race and online market outcomes," The Economic Journal 123 (2013), F469-F492.

Ewens, M., B. Tomlin And L. C. Wang, "Statistical discrimination or prejudice? A large sample field experiment," Review of Economics and Statistics (2014).

Finseraas, H. And A. Kotsadam, "Does Personal Contact with Ethnic Minorities Affect Support for Welfare Dualism? Evidence From a Field Experiment," Mimeo, Oslo University (2015).

FirTh, M., "Sex discrimination in job opportunities for women," Sex Roles 8 (1982), 891-901. 
Guryan, J. And K. K. Charles, "Taste-based or Statistical Discrimination: The Economics of Discrimination Returns to its Roots," The Economic Journal 123 (2013), F417-F432.

Heckman, J. J., "Detecting discrimination," Journal of Economic Perspectives (1998), 101-116.

Heckman, J. J. And P. Siegelman, "The Urban Institute audit studies: Their methods and findings," (1993).

Hellum, N., "Sminkedritt over hele vasken - en kvalitativ feltstudie av kjønnsblandede rom og maskulinitetskultur i Forsvaret," Technical Report 2156, FFI, 2015 .

Kanter, R. M., Men and Women of the Corporation, volume 5049 (Basic books, 1977a).

"Some effects of proportions on group life: Skewed sex ratios and responses to token women," American journal of Sociology (1977b), 965-990.

Kling, J. R., J. B. Liebman and L. F. Katz, "Experimental Analysis of Neighborhood Effects," Econometrica 75 (2007), 83-119.

Levinson, R. M., "Sex discrimination and employment practices: An experiment with unconventional job inquiries," Social Problems 22 (1975), 533-543.

List, J. A., "The nature and extent of discrimination in the marketplace: Evidence from the field," The Quarterly Journal of Economics (2004), 49-89.

Manski, C., "Identification of Endogenous Social Effects: The Reflection Problem," The Review of Economic Studies 60 (1993), 531-542.

Midtbøen, A., "Segregering og diskriminering," in M. Teigen and R. Liza, eds., Kjønnsdeling og etniske skiller på arbeidsmarkedet (Gyldendal, 2014).

Neumark, D., "Detecting discrimination in audit and correspondence studies," Journal of Human Resources 47 (2012), 1128-1157.

Neumark, D., R. J. Bank And K. D. VAN Nort, "Sex Discrimination in Restaurant Hiring: An Audit Study*," The Quarterly journal of economics 111 (1996), 915-941. 
PAGER, D., "The use of field experiments for studies of employment discrimination: Contributions, critiques, and directions for the future," The Annals of the American Academy of Political and Social Science 609 (2007), 104-133.

Pande, R. And D. Ford, "Gender quotas and female leadership: A review," (2011)

Petit, P., "The effects of age and family constraints on gender hiring discrimination: A field experiment in the French financial sector," Labour Economics 14 (2007), 371-391.

Pettigrew, T. F., "Intergroup Contact Theory," Annual Review of Psychology 49 (1998), 65-85.

Phelps, E. S., "The statistical theory of racism and sexism," The American Economic Review (1972), 659-661.

Riach, P. A. AND J. Rich, "TESTING FOR SEXUAL DISCRIMINATION IN THE LABOUR MARKET*," Australian Economic Papers 26 (1987), 165178.

, "Field Experiments of Discrimination in the Market Place*," The economic journal 112 (2002), F480-F518.

"An experimental investigation of sexual discrimination in hiring in the English labor market," Advances in Economic Analysis \& Policy 5 (2006).

RICH, J., "What Do Field Experiments of Discrimination in Markets Tell Us? A Meta Analysis of Studies Conducted since 2000," (2014).

Ridgeway, C. L. And S. J. Correll, "Unpacking the gender system a theoretical perspective on gender beliefs and social relations," Gender 8 society 18 (2004), 510-531.

Sacerdote, B., "Peer Effects in Education: How Might They Work, How Big Are They and How Much Do We Know Thus Far?," in E. A. Hanushek, S. J. Machin and L. Woessmann, eds., Handbook of the Economics of Education (Elsevier, 2011).

Schwab, K., B. Brende, S. Zahidi, Y. Bekhouche, A. Guinault, A. Soo, R. Hausmann and L. Tyson, The Global Gender Gap Report, volume 6 (World Economic Forum, 2014). 
Semyonov, M., R. Raijman and A. Gorodzeisky, "The Rise of AntiForeigner Sentiment in European Societies, 1988-2000," American Sociological Review 71 (2006), 426-449.

StatisticsNorway, "Names 2014," (2014).

Teigen, M., "Kjønnsdeling på langs," in M. Teigen and R. Liza, eds., Kjønnsdeling og etniske skiller på arbeidsmarkedet (Gyldendal, 2014).

Van Laar, C., S. Levin, S. Sinclair and J. Sidanius, "The effect of university roommate contact on ethnic attitudes and behavior," Journal of Experimental Social Psychology 41 (2005), 329-345.

Weichselbaumer, D., "Is it sex or personality? The impact of sex-stereotypes on discrimination in applicant selection," Univ. of Linz Economics Working Paper (2000).

Zhou, X., J. Zhang and X. Song, "Gender Discrimination in Hiring: Evidence from 19,130 Resumes in China," (2013).

Zussman, A., "Ethnic discrimination: Lessons from the Israeli online market for used cars," The Economic Journal 123 (2013), F433-F468. 


\section{Appendix}

\section{Question wordings and recoding of survey items}

Do your parents have higher education (university/college)?

Categories: $1=$ Yes, both have higher education, $2=$ My father has higher education, my mother has not, $3=$ My mother has higher education, my father has not, $4=$ No, neither of them have higher education

Recode: We recode into two variables: Father has high education $(1 / 2=1,3 / 4$ $=0)$ and Mother has high education $(1 / 3=1,2 / 4=0)$

Are your parents in work?

Categories: $1=$ Yes, both, $2=$ My father is in work, my mother is not, $3=\mathrm{My}$ mother is in work, my father is not, $4=\mathrm{No}$, neither of them is in work

Recode: We recode into two variables: Father is employed $(1 / 2=1,3 / 4=0)$ and Mother is employed $(1 / 3=1,2 / 4=0)$

Are your parents divorced/separated?

Categories: $1=$ Yes, $2=$ No, $3=$ Don't know

Recode: 3 to missing.

Do you plan to take higher education? Categories: $1=$ No, $2=$ Yes

Recode: We rely on the original coding

The IQ measure is a composite score from three speeded ability tests of arithmetics, word similarities, and figures. These results are provided to us from the military registers. The composite test score is an unweighted mean of the three subtests. The scores are reported in stanine (Standard Nine) units, a method of standardizing raw scores into a nine point standard scale with a normal distribution (mean $=5, \mathrm{SD}=2$ ).

\section{Results when including women in the vignette experiment}

In the main analysis we restrict the sample to only include men as this is a necessary restriction in analyzing peer effects. It is not necessary to exclude 
them in the initial analyzes, however, and we here present the first set of results when all individuals are included and we also test if there is differential discrimination for men and women in the sample. In Table 10 we see the raw difference across cases in how they are evaluated as squad leaders when all individuals are included and the results are very similar to the ones presented in the main text.

In Table 11 we estimate equation 1 for the whole sample and we also test for gender differences in the discrimination by including an indicator variable for female respondents and interacting this variable with female candidate. In column 1 we see that the woman is evaluated as less fit for being a squad leader in the total sample. In column 2 we see that female respondents evaluate the female candidates statistically significantly better and by adding terms we cannot reject that women do not discriminate against neither the male nor the female candidate. In column 3 we show the difference in difference results for the whole sample and note that they are similar and in column 4 we interact all terms with being a female respondent. Doing this, we do not find any evidence of that men and women interpret the information differently.

Table 10: Descriptive statistics across assigned cases

\begin{tabular}{|c|c|c|c|c|c|c|c|c|}
\hline & \multicolumn{2}{|c|}{$\begin{array}{c}(1) \\
\text { Ida less info }\end{array}$} & \multicolumn{2}{|c|}{$\begin{array}{c}(2) \\
\text { Martin less info }\end{array}$} & \multicolumn{2}{|c|}{$\begin{array}{c}(3) \\
\text { Ida more info }\end{array}$} & \multicolumn{2}{|c|}{$\begin{array}{c}(4) \\
\text { Martin more info }\end{array}$} \\
\hline & Mean & $\mathrm{SD}$ & Mean & $\mathrm{SD}$ & Mean & $\mathrm{SD}$ & Mean & $\mathrm{SD}$ \\
\hline Dependent variable & & & & & & & & \\
\hline $\begin{array}{c}\text { Score on the candidate } \\
(1=\text { very bad, } 6=\text { very good })\end{array}$ & 3.816 & $(1.018)$ & 4.144 & $(0.955)$ & 4.405 & $(0.888)$ & 4.727 & $(0.823)$ \\
\hline Background characteristics & & & & & & & & \\
\hline Mother has high education & 0.775 & $(0.420)$ & 0.628 & $(0.486)$ & 0.703 & $(0.459)$ & 0.653 & $(0.478)$ \\
\hline Father has high education & 0.887 & $(0.318)$ & 0.802 & $(0.401)$ & 0.822 & $(0.385)$ & 0.802 & $(0.400)$ \\
\hline Mother works & 0.850 & $(0.359)$ & 0.884 & $(0.322)$ & 0.860 & $(0.349)$ & 0.891 & $(0.313)$ \\
\hline Father works & 0.950 & $(0.219)$ & 0.965 & $(0.185)$ & 0.990 & $(0.100)$ & 0.970 & $(0.171)$ \\
\hline Parents are divorced & 0.263 & $(0.443)$ & 0.256 & $(0.439)$ & 0.373 & $(0.486)$ & 0.270 & $(0.446)$ \\
\hline Plan higher education & 0.762 & $(0.428)$ & 0.640 & $(0.483)$ & 0.794 & $(0.406)$ & 0.762 & $(0.428)$ \\
\hline IQ & 5.782 & $(1.466)$ & 5.562 & $(1.314)$ & 5.845 & $(1.557)$ & 5.606 & $(1.381)$ \\
\hline $\mathrm{N}$ (on dependent variable) & 87 & & 90 & & 111 & & 110 & \\
\hline
\end{tabular}


Table 11: Gender discrimination including both sexes: Dependent variable is score of the candidate.

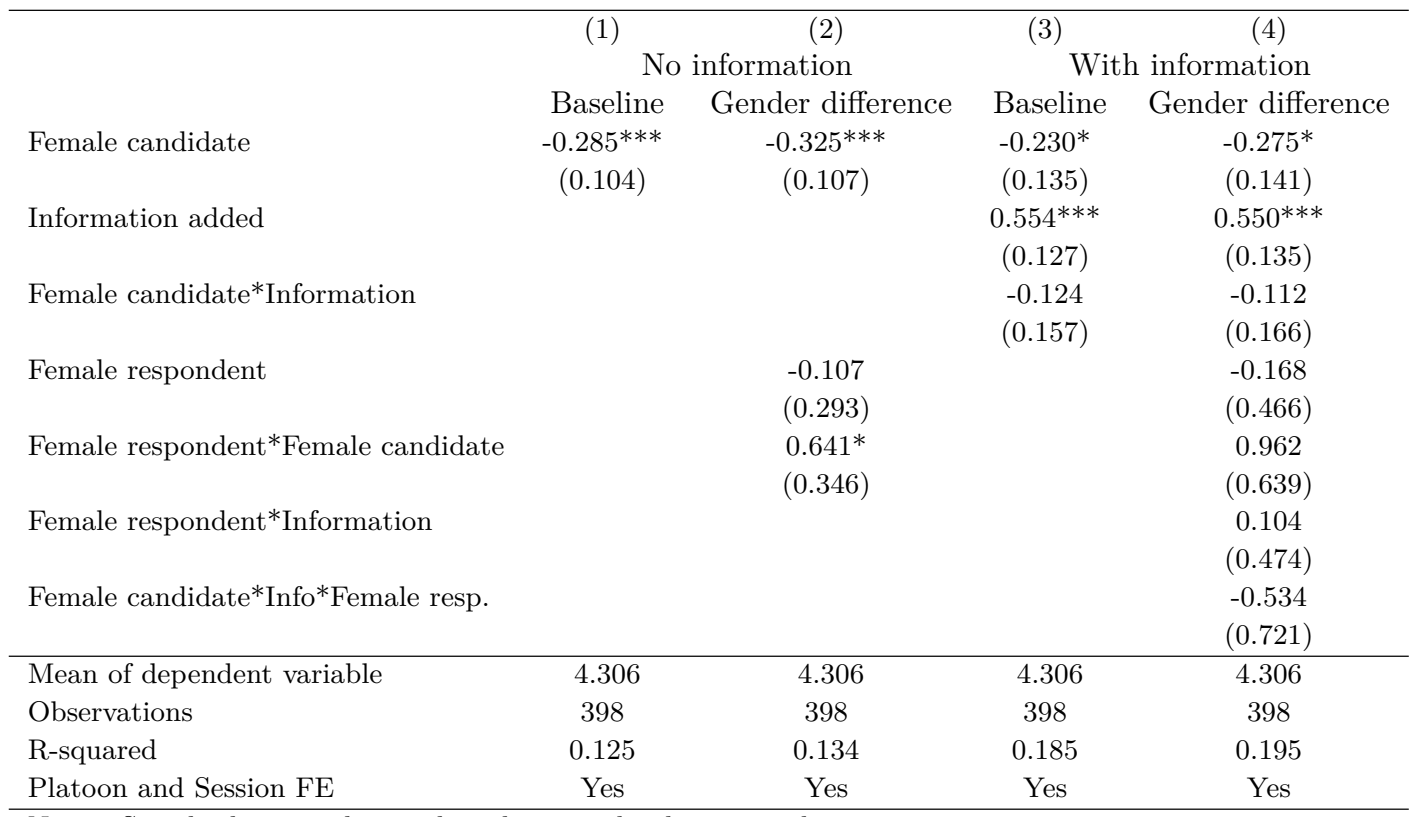

Notes: Standard errors clustered at the room level in parantheses. 